\title{
Check dam sediments: an important indicator of the effects of environmental changes on soil erosion in the Loess Plateau in China
}

\author{
Yafeng Wang • Liding Chen • Bojie Fu • Yihe Lü
}

Received: 17 October 2013 / Accepted: 20 February 2014 / Published online: 13 March 2014

(C) Springer International Publishing Switzerland 2014

\begin{abstract}
Check dam sediments document the process of soil erosion for a watershed. The main objectives of this research are as follows: first, to determine whether the sediments trapped in check dams can provide useful information about local erosion and the environment, and second, to obtain the extent to which they can be stratigraphically interpreted and correlated to the land use history of an area controlled by check dams. Particle size and the concentration of ${ }^{137} \mathrm{Cs}$ in sediments are the indicators used to study the effects of environmental changes on soil erosion in the Loess Plateau, China. A total of 216 soil samples were collected from four sediment profile cores at the Yangjuangou watershed check dam constructed in 1955 and fully silted with sediments by 1965 . The results indicated that ${ }^{137} \mathrm{Cs}$ dating and sediment particle size can characterize the sediment deposition process. Silt makes up more than $50 \%$ of the sediment; both the clay and silt sediment fractions decrease gradually in the upstream direction. The sediment profiles are characterized by three depositional layers. These layers suggest changes in the land use. The top layer showed tillage disturbance, with moderate
\end{abstract}

Y. Wang $\cdot$ L. Chen $\cdot$ B. Fu $(\bowtie) \cdot$ Y. Lü

State Key Laboratory of Urban and Regional Ecology, Research Center for Eco-Environmental Sciences, Chinese Academy of Sciences,

P. O. Box 2871, Beijing 100085, People's Republic of China e-mail: bfu@rcees.ac.cn

Y. Wang

Stay Key Laboratory of Loess and Quaternary Geology, Institute of Earth Environment Chinese Academy of Sciences, Xi'an 710075, People's Republic of China sediments and new soil mixed from 0 to $20 \mathrm{~cm}$. A transition stage from wetlands (characterized by vegetation such as bulrush) to cropland is inferred from sediments at depths of 20-85 cm. Below $85 \mathrm{~cm}$, sedimentary layering is obvious and there is no tillage disturbance. At the downstream site, A0, the average rate of sediment deposition from 1958 to 1963 was approximately 6,125.4 $\mathrm{t}_{\text {year }}{ }^{-1} \mathrm{~km}^{-2}$. Because of their high time resolution, check dam sediments indicate the effects of environmental changes on soil erosion, and they can provide a multiyear record of the soil erosion evolution at the local scale in the middle reaches of the Yellow River.

Keywords Check dam · Sediment $\cdot{ }^{137} \operatorname{Cs}(137-$ Cesium) $\cdot$ Soil erosion $\cdot$ Environmental change

\section{Introduction}

Sediments are one of the most efficient indicators for revealing the function of modern ecosystems and landscapes (Dearing et al. 2001, 2008). Soil erosion, with the accompanying sediment transportation and deposition, provides insight into environmental change. Land use changes and hydrological engineering projects undertaken in catchments affect fluvial dynamics, as evidenced by the morphological evolution of river beds (Boix-Fayos et al. 2005). Land use changes and erosion control projects may induce strong geomorphic responses in catchments, which can be reflected in the morphological evolution of river channels (Boix-Fayos 
et al. 2007). In addition to the natural processes leading to channel change, land use changes and erosion control projects need to be understood in a historical and evolutionary context to better understand how these controls change river form and processes (Dollar 2004). Therefore, catchment-scale land use changes are crucial to understanding the evolution of sediment load and discharge dynamics.

The Loess Plateau covers an area of approximately $640,000 \mathrm{~km}^{2}$ in the upper and middle reaches of the China's Yellow River. Over $60 \%$ of the land is susceptible to soil and water losses; the soil of this region has been called the "most highly erodible soil on earth" (Laflen 2000). The most crucial areas, the Loess Mesa Ravine Region and the Loess Hill Ravine Region, cover $30 \%$ of the total area and have some of the most severe soil and water losses in the world. Erosion averages $5,000-10,000 \mathrm{t} \mathrm{km}^{-2}$ year $^{-1}$ and occasionally reaches 20,000-30,000 t km${ }^{-2}$ year $^{-1}$ (Meng 1996).

Soil erosion is a selective process of soil redistribution in the landscape. This spatial redistribution is directly associated with variations of soil quality (Mabit et al. 2010). Evidence of the impact of soil erosion on agricultural land along with its off-site impacts (i.e., siltation, diffuse pollution, water eutrophication) is mounting. This emphasizes the need for a quantitative assessment of recent erosion rates to develop and assess erosion control technology and to allocate conservation resources and develop conservation regulation policies and programs (Stroosnijder 2005; Pimentel et al. 1995; Schuller et al. 2007).

The use of fallout radionuclides, especially ${ }^{137} \mathrm{Cs}$, can complement the information provided by conventional erosion measurements and modeling (Fu et al. 2009). ${ }^{137} \mathrm{Cs}$ was released into the environment as a result of atmospheric testing of thermo-nuclear weapons during the period from the 1950s to the 1970s. It is an artificial radionuclide with a half-life of 30.17 years and a maximum deposition rate in 1963. ${ }^{137} \mathrm{Cs}$ fallout was strongly and rapidly adsorbed by fine particles in the surface soil when it was deposited on the ground mostly by precipitation; its transport was associated with soil or sediment particles (Li and Wei 2011; Ritchie et al. 2003; Walling et al. 1997; Walling and He 1997; Zhang et al. 1990). The subsequent redistribution of ${ }^{137} \mathrm{Cs}$ occurs when the soil and sediment particles move. Measurements of the present-day distribution of ${ }^{137} \mathrm{Cs}$ can provide a quantitative estimate of soil erosion and deposition rates since the ${ }^{137} \mathrm{Cs}$ was deposited from the atmosphere ( $\mathrm{Li}$ et al.
2003). The fallout has been widely used for assessments of soil erosion rates, dating of sediment deposits, and investigations of sediment sources since the 1980s (Fang et al. 2012).

Check dams are used to control soil and water loss in the Loess Plateau region. The main functions of these dams are to stop and store sediments, fix gully beds, raise the eroded base surface, and prevent gully beds undercutting and gully bank expansion (Li 2001). Currently, more than 110,000 check dams have been constructed; these check dams retain a considerable amount of sediments (Xu et al. 2004). Moreover, the Chinese Ministry of Water Resources has stated that 163,300 check dams will be built in this area before 2020 (CMWR 2003).

The sediments trapped by check dams can serve as natural archives for reconstructing the environmental history of soil erosion at a given location. Typically, the relationship between sediments and climate change are studied in lacustrine, littoral, and sublittoral habitats and pelagic mass-water circulations (Jennings et al. 2001; Wasson et al. 2002; Girardclos et al. 2005; Picot et al. 2005; Lu et al. 2006; Vott et al. 2006; Fanetti and Vezzoli 2007; Kaiser et al. 2009). Such studies reflect the relationships between sediments and environmental change over a long period of time (Miao et al. 2010, 2011, 2012). Meanwhile, physical model, Google Earth images and field survey are used to derive the spatial distribution of the check dams in Loess Plateau of China (Zheng et al. 2013; Tian et al. 2013; Xu et al. 2009).

Only a few studies compare the effects of short-term or contemporary environmental changes on soil erosion by sediments found in check dams (Nadal-Romero et al. 2008; Bellin et al. 2009). To control soil erosion, the Chinese government has constructed a large number of check dams in the Loess Plateau. The check dams are formed characteristics of a spatial and temporal distribution sequence. Because of the extensive soil erosion in the Loess Plateau region, sediments are deposited behind the check dam. There is great potential to use these sediments for high-resolution environmental change research based on soil erosion in the hilly Loess Plateau.

The main objectives of this research were to determine whether the sediments trapped in check dams can provide useful local erosion and environmental information, and to determine the extent to which they can be stratigraphically interpreted and correlated to land use history in the area controlled by the check dams. We 
focused on the sedimentation path and the link between erosional and depositional areas by measuring the sediment profile with ${ }^{137} \mathrm{Cs}$ dating and sedimentological analyses. These investigations can serve as a basis for contemporary climatic interpretation of erosional deposits. Furthermore, quantitative estimations from a selected sediment trap enable an evaluation of the depositional dynamics during the period of the check dam siltation and the influence of anthropogenic activity on local semiarid ecosystems.

\section{Materials and methods}

Study area

The study area is the Yangjuangou watershed (lat. $36^{\circ}$ $42^{\prime} \mathrm{N}$, long. $109^{\circ} 31^{\prime} \mathrm{E}$ ) in the middle part of the Loess Plateau in northern Shaanxi Province, China (Fig. 1). It is $14 \mathrm{~km}$ south of Yan'an City and covers an area of $2.02 \mathrm{~km}^{2}$. The Yangjuangou is a secondary tributary of the Yanhe River, which drains into the Yellow River. Topographic variations within the loess hills and gully landforms of the study area include a difference in altitude from hilltop to gully bottom of $225 \mathrm{~m}$ and a gully density of $2.74 \mathrm{~km} / \mathrm{km}^{2}$. The climate is semiarid continental with an average annual rainfall of $535 \mathrm{~mm}$. The rainfall mainly occurs between July and September with large interannual variations. The soil is mainly derived from loess with a texture ranging from fine silt to silt and is vulnerable to erosion ( $\mathrm{Fu}$ et al. 2000). The erosion rate is high with an average soil loss of $8,979 \mathrm{t} \mathrm{km}^{-2}$ year $^{-1}$ between 1991 and 1996 ( $\mathrm{Li}$ et al. 1997). The planted forests on the hillslopes include Pinus tabulaeformis and Robinia pseudoacacia. The natural grasses in the catchment include Bothriochloa ischaemum, Themeda triandra var. japonica, and Carex filipes. The crops grown in the agricultural areas include corn, potatoes, beans, and millet.

Check dam I was constructed during 1954-1955 on the upper-middle branch of the Yangjuangou catchment and was filled with sediments by 1965. It was the first check dam in the Yan'an area and controls an area of $0.65 \mathrm{~km}^{2}$ (Fig. 1). The dam height is $7 \mathrm{~m}$, the width is $40 \mathrm{~m}$, and the length is $260 \mathrm{~m}$. The warp land area is approximately $1.04 \times 10^{4} \mathrm{~m}^{2}$, and land use is mainly farm land with corn, potatoes, and beans.
Soil sampling and laboratory analysis

Sediment samples were collected in the catchment for ${ }^{137} \mathrm{Cs}$ analysis in June 2006. Soil sampling was performed from head to tail along the check dam silted plane. We collected four sediment deposit profiles from the deposit bottom to the surface, and we carefully sectioned the profiles to reflect the flood couplets. The core sediments were undisturbed, as indicated by the clear water-sediment interface and the preservation of fine sediment laminations. The boundary between the couplets associated with individual floods was easily defined because the bottom layer in a couplet was coarse while the top was fine (Zhang et al. 2006). Each couplet was usually subdivided into three samples; however, a few were divided into two or four samples. The thickness of a couplet varied from a few centimeters to several decimeters. We collected 73, 69, 46, and 30 sediment samples from the A0, A1, A2, and A3 cores, respectively (Figs. 2 and 3).

We air dried, crushed, and sieved the soil samples through a 2-mm mesh sieve to remove the gravel. Samples with a particle size fraction of $<2 \mathrm{~mm}$ were packed into $320 \mathrm{~cm}^{3}$ plastic beaker. We measured ${ }^{137} \mathrm{Cs}$ activity using a hyperpure lithium-drifted germanium detector coupled to a Nuclear Data 6700 multichannel g-ray spectrophotometer with a counting time of $28,000-40,000 \mathrm{~s}$.

We analyzed soil samples with the laser diffraction technique using a Mastersizer 2000 laser particle size analyzer (Malvern Instruments, Malvern, England). Measurements were taken for an interval of sizes ranging from 0.02 to $2,000 \mu \mathrm{m}$. Soil particle size fractions were determined by Mastersizer 2000 to characterize soil volume-size particle distributions.

${ }^{137}$ Cs dating

${ }^{137} \mathrm{Cs}$ can provide up to four time marks when dating sediment sections, commencing with its first appearance in the environment around 1954 (Ritchie and Mchenry 1990; Ritchie et al. 2004; Ayrault et al. 2010).

The ${ }^{137} \mathrm{Cs}$ depth distribution in a depositional sink, such as floodplains, will in the best situations include two peaks of global fallout (dated to 1958-1959 and 1963-1964, respectively) and the Chernobyl-associated tertiary peak dated to 1986 (Klaminder et al. 2012). However, the fallout peak dated to $1958-1959$ is 


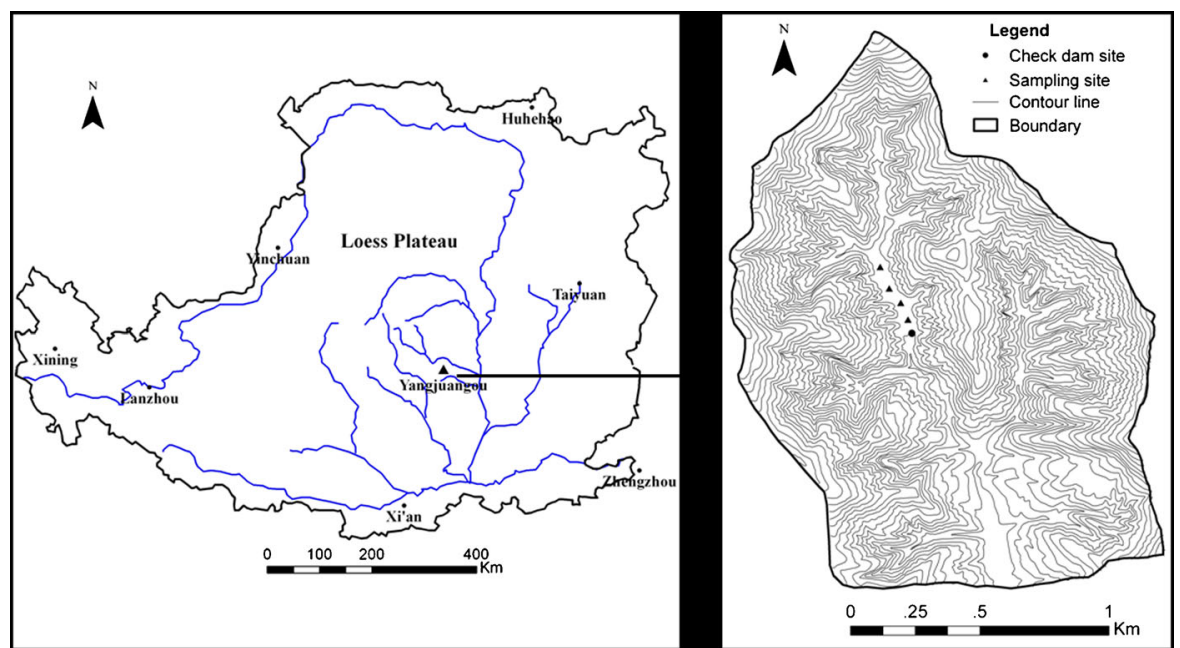

Fig. 1 Locations of Yangjuangou watershed and sediment sampling sites

often not easy to identify in most of the floodplain cores.

The loess plateau has a large number of check dams. Due to high deposition rates, the $1963{ }^{137} \mathrm{Cs}$ fallout peak is easily identified in profiles obtained from the sediments of the check dam. ${ }^{137} \mathrm{Cs}$ dating, supported by morphological surveys, permitted sediment storage volumes to be determined, and this provided the basis for estimating specific sediment yields and average erosion rates (Zhang et al. 2007, 2011).

\section{Statistical analysis}

We developed the figures using Origin v.8.0 and Microsoft Excel 2003, and used descriptive analysis to compare the concentrations of ${ }^{137} \mathrm{Cs}$ and soil particle size for different cores. All differences reported in the text were tested and considered significant at $\alpha=0.05$.

\section{Results}

Distribution characteristics of sediment size and ${ }^{137} \mathrm{Cs}$

As shown in Figs. 1 and 2, the four soil cores are distributed along the check dam from upstream (core A3) to downstream (core A0). Figure 3 shows the distribution characteristics of sediment clay fractions for all four cores. The profile variation of clay sediment fractions decreases gradually from A0 to A3. Table 1 provides the particle size distribution, coefficient of variation, and ${ }^{137} \mathrm{Cs}$ activity for the four cores. At the $\mathrm{A} 0$ and A1 sites, the percentage of clay fractions is 4.36$10.32 \%$ and $4.37-12.79 \%$, respectively, with an average of 6.83 and $6.71 \%$ and a coefficient of variation (CV) of 0.25 and 0.29 (Table 1). At the A2 and A3 sites, the percentage of clay fractions is $4.46-.78 \%$ and 5.44 $7.66 \%$, respectively, with an average of 6.57 and $6.36 \%$ and a CV of 0.16 and 0.09 . Except for the $100-140 \mathrm{~cm}$ depth at the A0 site, the clay fractions are reasonably consistent in all four cores from 0 to $200 \mathrm{~cm}$. Generally, the sediment clay fraction is higher in the downstream portion of the check dam and lower in the upstream portion.

Figure 4 shows the distribution characteristic of sediment silt fractions in the four cores. In general, silt accounts for more than $50 \%$ of the sediments in the cores. From A0 to A3, the profile variations of sediment silt fractions gradually decrease. In all cores from 0 to $200 \mathrm{~cm}$, the variation of silt is lower than the variations observed deeper than $200 \mathrm{~cm}$. At the A0 and A1 sites, the percentage of silt fractions is 52.94$89.24 \%$ and 55.39-88.35\%, respectively, with an average of 71.59 and $70.17 \%$ and a $\mathrm{CV}$ of 0.13 and 0.12 . At the $\mathrm{A} 2$ and $\mathrm{A} 3$ sites, the percentage of silt fractions is 55.0-88.02 \% and 61.45-75.51\%, respectively, with an average of 66.72 and $66.85 \%$ and a CV of 0.08 and 0.05 . 
Fig. 2 Photos of the check dam landscape, sampling process, deposition layer, and sites of the four sampling cores
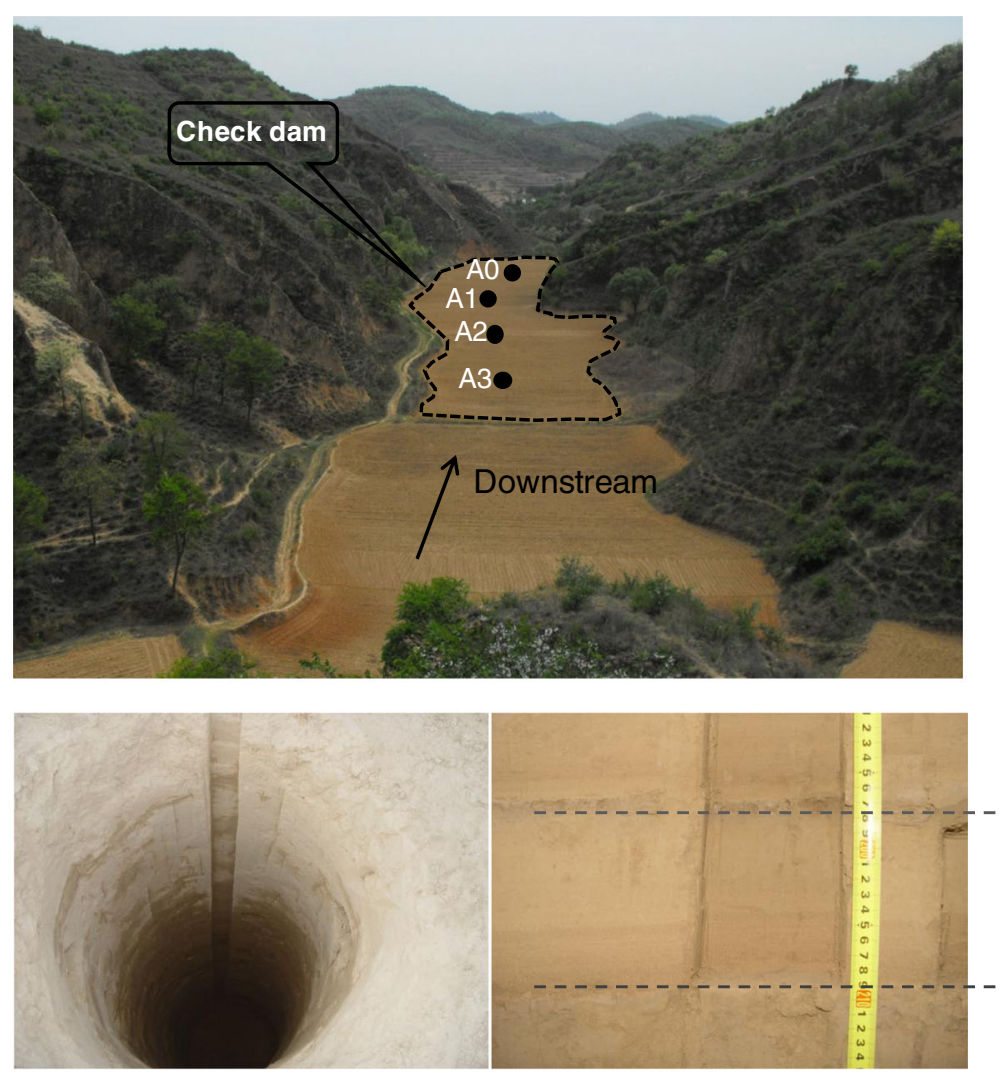

Length of Check Dam (m)

$0204060 \quad 80100120140160180200220240260280$

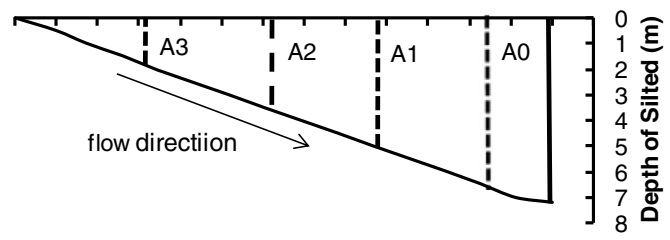

The ${ }^{137} \mathrm{Cs}$ activities in cores show a similar pattern (Fig. 6). At A0 and A1, the ${ }^{137} \mathrm{Cs}$ activities is $0.08-7.91$ and $0-7.67 \mathrm{~Bq} \mathrm{~kg}^{-1}$, respectively, with an average of 2.70 and $1.71 \mathrm{~Bq} \mathrm{~kg}^{-1}$, and the $\mathrm{CV}$ is 0.75 and 0.86 (Table 1). At the A2 and A3 sites, the percentage of ${ }^{137} \mathrm{Cs}$ activities is, respectively, $0-7.25$ and $0-$ $5.21 \mathrm{~Bq} \mathrm{~kg}^{-1}$, the average is 1.86 and $2.01 \mathrm{~Bq} \mathrm{~kg}^{-1}$, and the $\mathrm{CV}$ is 0.81 and 0.73 . The $0-150-\mathrm{cm}$ interval shows a gradual increase in ${ }^{137} \mathrm{Cs}$ concentrations. A significant pulse is located at a depth of 100 $200 \mathrm{~cm}$, with the main peak at a depth of 120$160 \mathrm{~cm}$. This peak coincides with a delayed main pulse of nuclear weapons testing in 1963 (Naegler and Levin 2006). 


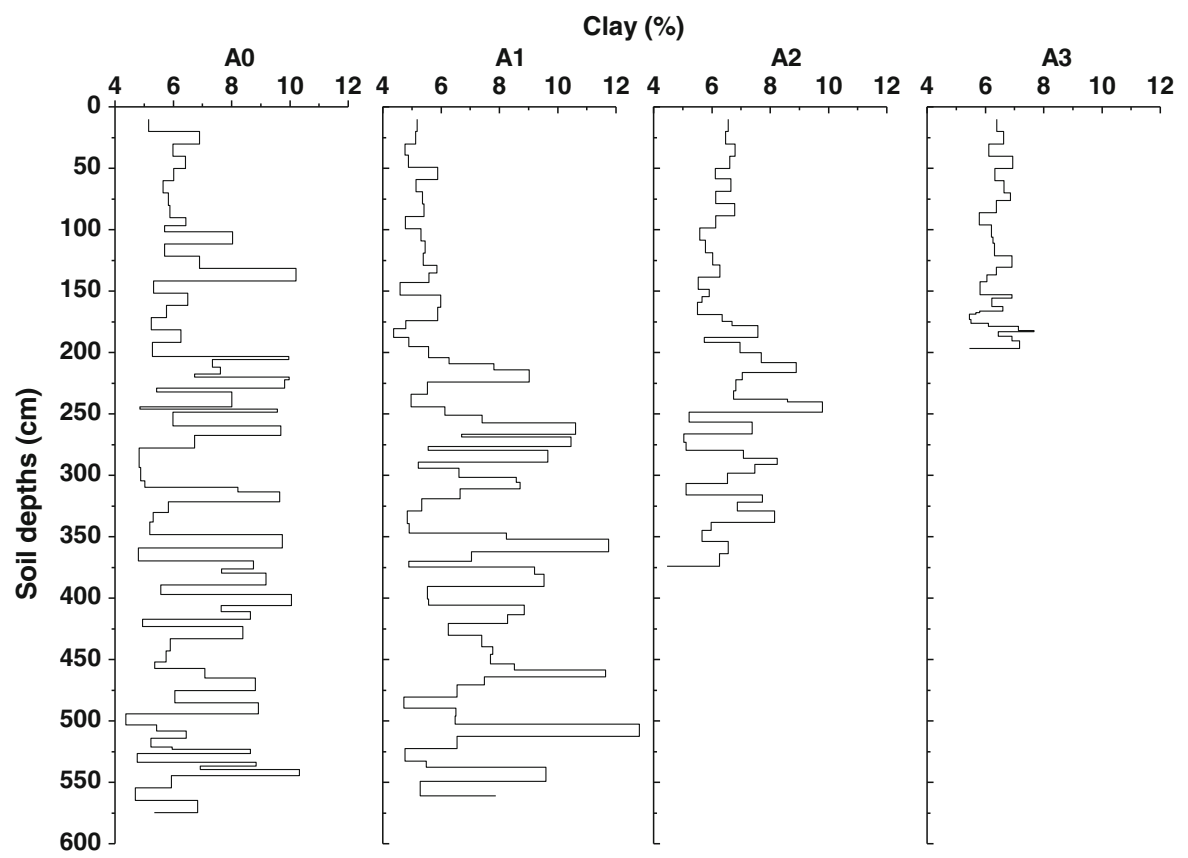

Fig. 3 Profile for sediment clay fractions from A0 to A3

Characteristics of historical rainfall events and ${ }^{137} \mathrm{Cs}$ profile distribution

After the check dam was constructed, sediment accumulated in the deposit profile after every erosive rainfall-runoff event because of the trapping effect of the check dam. Kou et al. (2007) and Wei et al. (2007) have indicated that, in the Loess Plateau, rainfall greater than $30 \mathrm{~mm}$ is considered erosive. We selected rainfall data from

Table 1 Coefficient of variation (CV) of particle size and ${ }^{137} \mathrm{Cs}$ activity in four cores

\begin{tabular}{|c|c|c|c|c|c|c|c|}
\hline Core no. & Indexes & No. & Mean & SD & Min & $\mathrm{CV}$ & Max \\
\hline \multirow[t]{4}{*}{ A0 } & Clay (\%) & 73 & 6.83 & 1.72 & 4.36 & 0.25 & 10.32 \\
\hline & Silt (\%) & & 71.59 & 9.02 & 52.94 & 0.13 & 89.24 \\
\hline & Sand (\%) & & 21.57 & 10.53 & 0.95 & 0.49 & 42.37 \\
\hline & ${ }^{137} \mathrm{Cs}\left(\mathrm{Bq} \mathrm{kg}{ }^{-1}\right)$ & & 2.70 & 2.02 & 0.08 & 0.75 & 7.91 \\
\hline \multirow[t]{4}{*}{ A1 } & Clay (\%) & 69 & 6.71 & 1.97 & 4.37 & 0.29 & 12.79 \\
\hline & Silt (\%) & & 70.17 & 8.65 & 55.39 & 0.12 & 88.35 \\
\hline & Sand $(\%)$ & & 23.09 & 10.28 & 1.20 & 0.45 & 39.00 \\
\hline & ${ }^{137} \mathrm{Cs}\left(\mathrm{Bq} \mathrm{kg}^{-1}\right)$ & & 1.71 & 1.48 & 0.00 & 0.86 & 7.67 \\
\hline \multirow[t]{4}{*}{ A2 } & Clay (\%) & 46 & 6.57 & 1.08 & 4.46 & 0.16 & 9.78 \\
\hline & Silt (\%) & & 66.72 & 5.66 & 55.00 & 0.08 & 88.02 \\
\hline & Sand $(\%)$ & & 26.71 & 6.57 & 2.18 & 0.25 & 39.90 \\
\hline & ${ }^{137} \mathrm{Cs}\left(\mathrm{Bq} \mathrm{kg}^{-1}\right)$ & & 1.86 & 1.50 & 0.00 & 0.81 & 7.25 \\
\hline \multirow[t]{4}{*}{ A3 } & Clay (\%) & 30 & 6.36 & 0.55 & 5.44 & 0.09 & 7.66 \\
\hline & Silt (\%) & & 66.85 & 3.20 & 61.46 & 0.05 & 75.51 \\
\hline & Sand (\%) & & 26.79 & 3.54 & 17.59 & 0.13 & 33.10 \\
\hline & ${ }^{137} \mathrm{Cs}\left(\mathrm{Bq} \mathrm{kg}{ }^{-1}\right)$ & & 2.10 & 1.53 & 0.00 & 0.73 & 5.21 \\
\hline
\end{tabular}


Silt (\%)

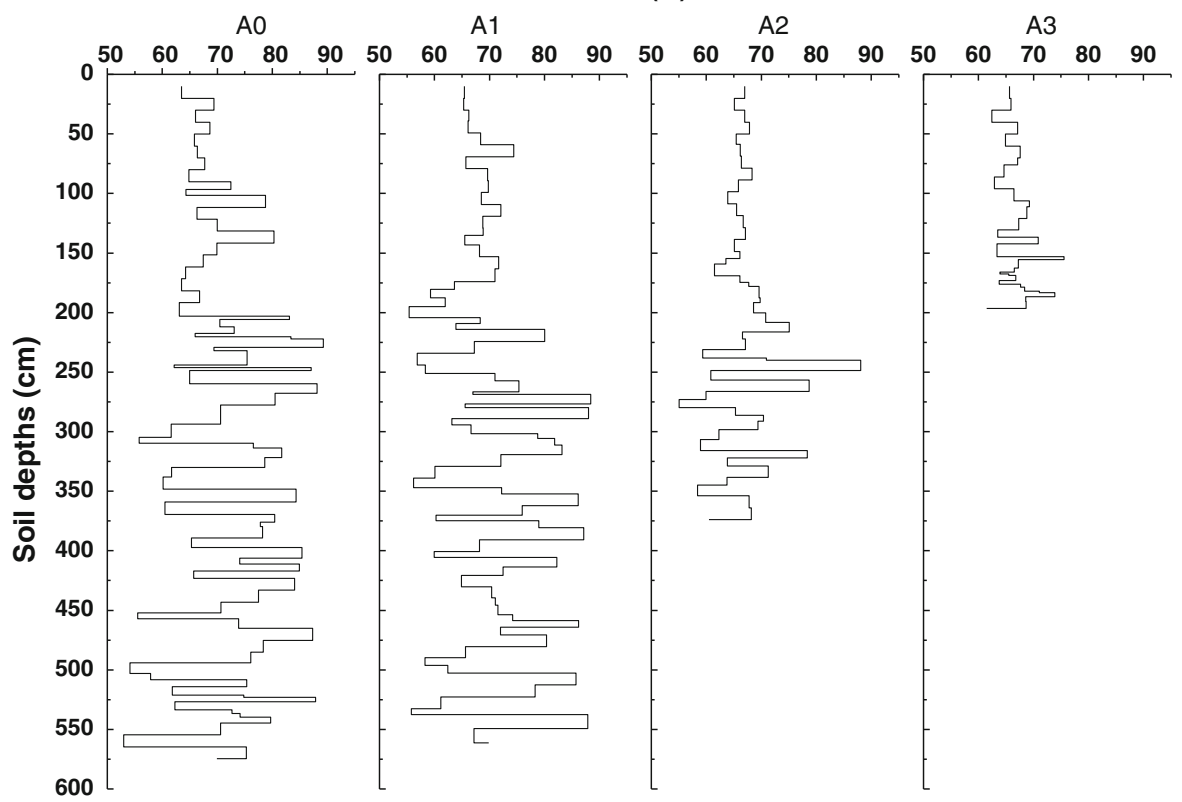

Fig. 4 Profile for sediment silt fractions from A0 to A3

1955 to 1966 based on the distribution of ${ }^{137} \mathrm{Cs}$ and the dates when the check dam was built and used. Accordingly, we selected all rainfall events with daily precipitation greater than $30 \mathrm{~mm}$
(Fig. 7). The largest single-day rainfall was nearly $105 \mathrm{~mm}$ on 11 August 1958. The second strongest rainfall event was more than $80 \mathrm{~mm}$ on 10 September 1963. There were 45 days with rainfall

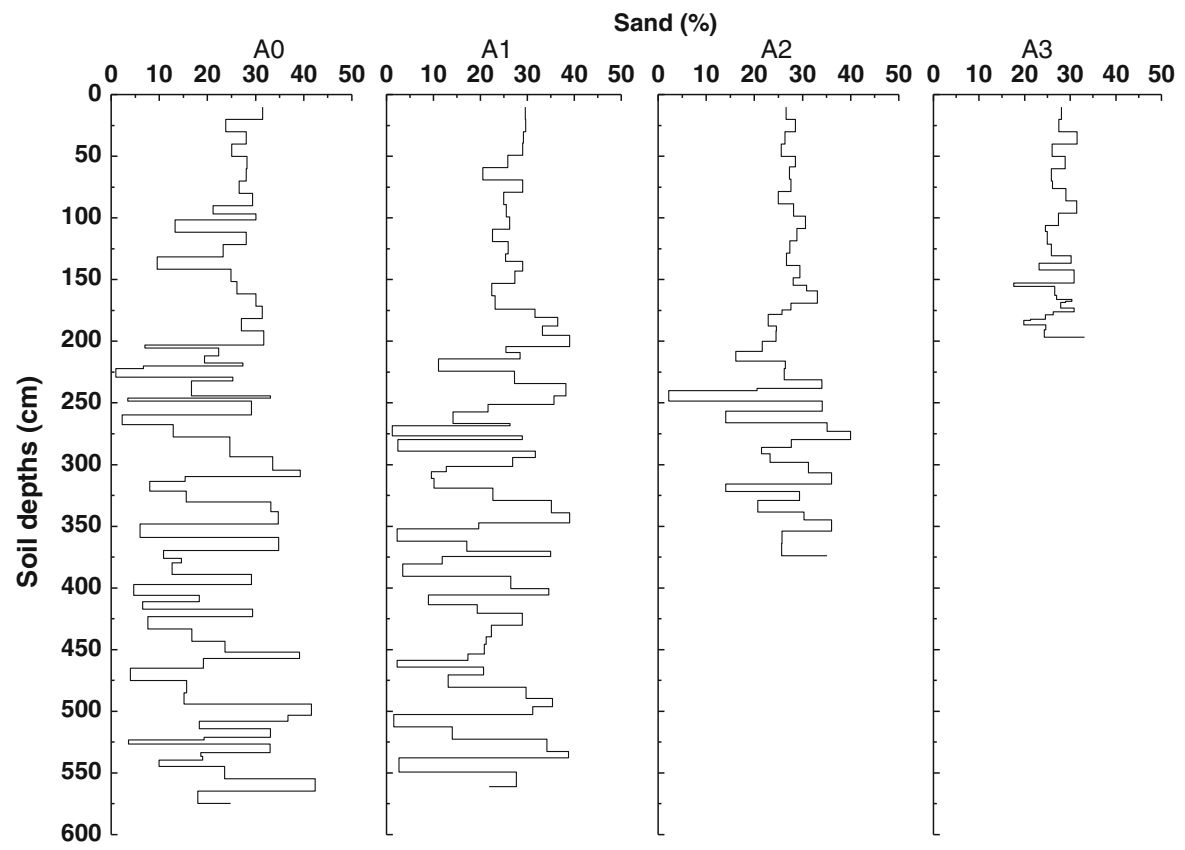

Fig. 5 Profile for sediment sand fractions from A0 to A3 


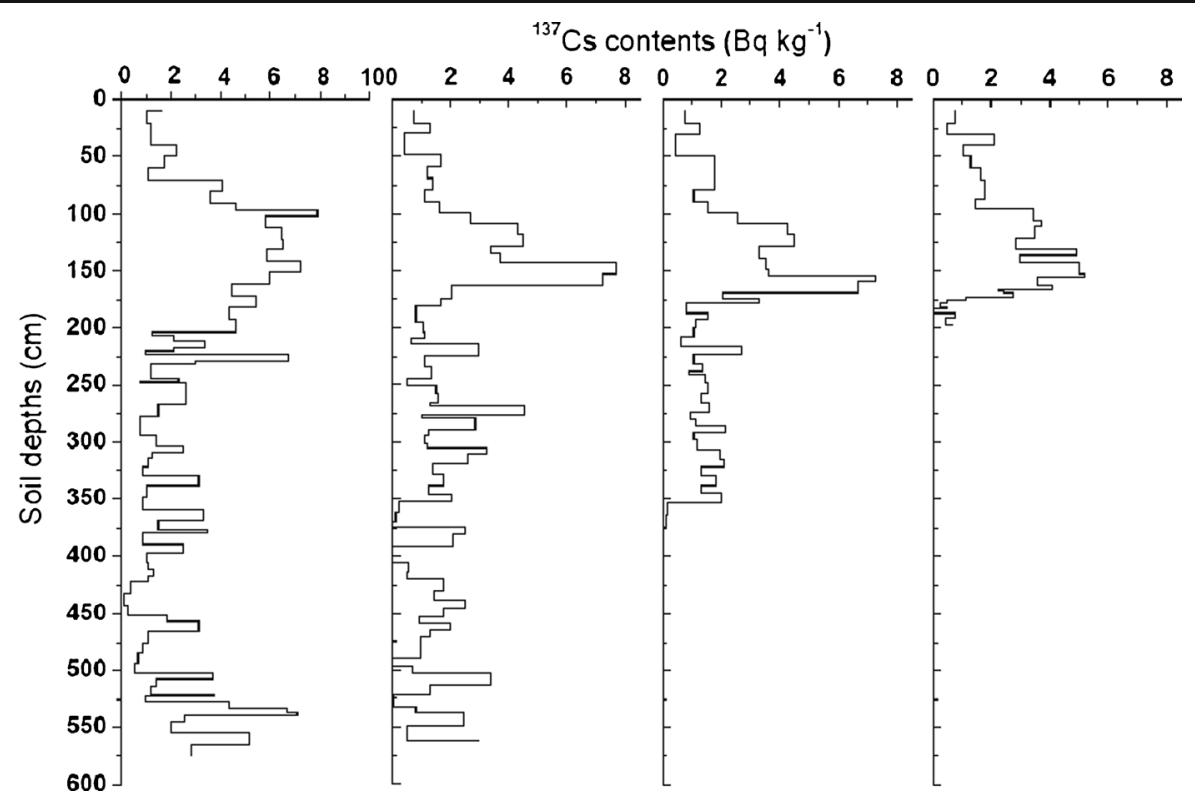

Fig. 6 Profile for sediment ${ }^{137} \mathrm{Cs}$ activity from A0 to A3

greater than $30 \mathrm{~mm}$. Therefore, the frequency of occurrence of an erosive rainfall is approximately 45 days. It is important to study historical rainfall events during the sediment deposition process.

Twenty-seven flood couplets were identified in the profile $(0-7.0 \mathrm{~m})$. The storm rainfalls, thicknesses, volumes, and specific sediment yield for those couplets are shown in Table 2. Sediments delivered from the upstream catchment were completely captured in the check dam from 1955 to 1965 . After 1965, another check dam was constructed at the food of check dam I, which prevented the sediments from the upstream region. Therefore, the deposited sediment volume in the reservoir can be considered as the sediment production during the period.

\section{Discussion}

Sediment size and ${ }^{137} \mathrm{Cs}$ in check dam

The higher clay and silt fractions in the downstream areas indicate that fine-grained sediments were transported farther in gullies during erosive rainfall-runoff events. Hassanli et al. (2009) stated that grain size distribution of sediments deposited behind check dams depends on the type of the sediments transported and the performance of the check dams in trapping the sediments. In this study, the check dam is a solid dam where both water and sediments are trapped. Consequently, a backwater condition develops, reducing the flow velocity. The reduced flow velocity leads to sedimentation of fine particles. Fine sediments need

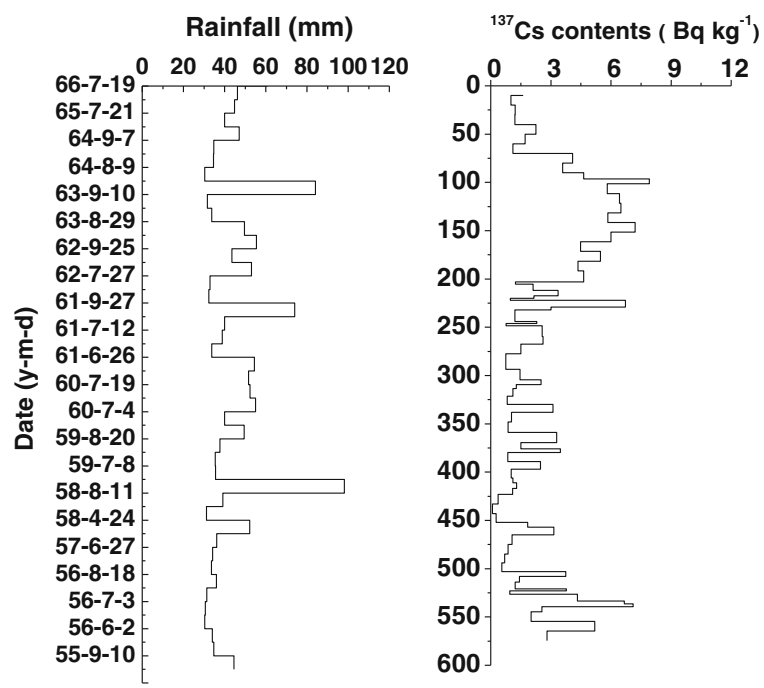

Fig. 7 Distribution of daily rainfall greater than $30 \mathrm{~mm}$ from 1955 to 1966 
Table 2 Related storm rainfalls, deposit volumes, and specific sediment yields of the 27 flood couplets from 1958 to 1964 in the Yangjuangou

\begin{tabular}{|c|c|c|c|c|c|}
\hline Flood couplets & $\begin{array}{l}\text { Date } \\
\text { (year/month/day) }\end{array}$ & $\begin{array}{l}\text { Storm } \\
\text { rainfall }(\mathrm{mm})\end{array}$ & $\begin{array}{l}\text { Depth in profile } \\
(\mathrm{cm})\end{array}$ & $\begin{array}{l}\text { Deposit } \\
\text { volume }\left(\mathrm{m}^{3}\right)\end{array}$ & $\begin{array}{l}\text { Specific sediment } \\
\text { yield }^{*}\left(\mathrm{t} \mathrm{km}^{-2}\right)\end{array}$ \\
\hline Cultivated layer & & & $0-85$ & $4,273.2$ & $8,546.4$ \\
\hline 1 & $1964 / 9 / 12$ & 40 & $85-96.5$ & 525.4 & $1,050.8$ \\
\hline 2 & $1963 / 9 / 10$ & 84.1 & $96.5-203$ & $4,774.5$ & $9,549.1$ \\
\hline 3 & $1963 / 9 / 06$ & 31.7 & $203-217.5$ & 535.3 & $1,070.7$ \\
\hline 4 & & & $217.5-220$ & 89.6 & 179.2 \\
\hline 5 & $1963 / 8 / 29$ & 33.8 & $220-229$ & 320.9 & 641.8 \\
\hline 6 & $1963 / 5 / 22$ & 49.7 & $229-244$ & 524.8 & $1,049.7$ \\
\hline 7 & & & $244-248.5$ & 152.4 & 304.9 \\
\hline 8 & $1962 / 9 / 25$ & 55.4 & $248.5-309.5$ & $2,045.9$ & $4,091.9$ \\
\hline 9 & $1962 / 8 / 25$ & 29.6 & $309.5-330$ & 565.7 & $1,131.3$ \\
\hline 10 & $1962 / 7 / 27$ & 53 & $330-359.5$ & 813.0 & $1,626.0$ \\
\hline 11 & $1962 / 7 / 18$ & 32.9 & $359.5-369.5$ & 253.7 & 507.4 \\
\hline 12 & $1961 / 9 / 27$ & 32.4 & $369.5-376$ & 160.1 & 320.1 \\
\hline 13 & $1961 / 8 / 13$ & 74.1 & $376-389$ & 342.8 & 685.7 \\
\hline 14 & $1961 / 7 / 12$ & 40 & $389-397$ & 184.7 & 369.4 \\
\hline 15 & 1961/7/01 & 38.9 & $397-406$ & 202.4 & 404.9 \\
\hline 16 & $1961 / 6 / 25$ & 54.5 & $406-417$ & 240.1 & 480.2 \\
\hline 17 & $1960 / 7 / 19$ & 51.7 & $417-452$ & 756.3 & $1,512.6$ \\
\hline 18 & & & $452-457$ & 91.7 & 183.3 \\
\hline 19 & $1960 / 7 / 04$ & 55.1 & $457-503$ & 826.3 & $1,652.5$ \\
\hline 20 & $1959 / 9 / 20$ & 40 & $503-521$ & 261.8 & 523.6 \\
\hline 21 & $1959 / 8 / 28$ & 29.2 & $521-523$ & 26.4 & 52.8 \\
\hline 22 & $1959 / 8 / 20$ & 49.5 & $523-533.5$ & 137.1 & 274.2 \\
\hline 23 & $1959 / 8 / 12$ & 29.9 & $533.5-536.5$ & 36.8 & 73.7 \\
\hline 24 & & & $536.5-539.5$ & 36.2 & 72.3 \\
\hline 25 & $1959 / 7 / 20$ & 37.8 & $539.5-564.5$ & 295.8 & 591.7 \\
\hline 26 & $1958 / 9 / 02$ & 35.6 & $564.5-624.5$ & 598.6 & 1,197.2 \\
\hline 27 & $1958 / 8 / 11$ & 98.1 & $624.5-700$ & 514.9 & $1,029.8$ \\
\hline
\end{tabular}

Bulk density of deposited sediment, $\gamma=1.3 \mathrm{t} \mathrm{m}^{-3}$. Because the delivering sediments from the upstream catchment were completely captured in the reservoir, the deposit volume of a flood couplet was representative of the delivering sediment volume and used for estimating the specific sediment yields

less energy than coarse sediments to be transported by water flow.

Likewise, ${ }^{137} \mathrm{Cs}$ contents in the downstream sediments of the check dam are higher than for sediments located in the middle and upstream areas. Based on characteristic soil erosion patterns in the Loess Plateau, sediments trapped behind the check dam are from gullies and sloped areas. ${ }^{137} \mathrm{Cs}$ is deposited as dry and wet fallout and is rapidly, and almost irreversibly, adsorbed into sediment, particularly clay and silt particles (Zhang et al. 2006; Walling et al. 2006; Walling 2005). The patterns of ${ }^{137} \mathrm{Cs}$ distribution indicate that the check dam caused higher inventories of ${ }^{137} \mathrm{Cs}$ near the check dam, thus demonstrating the tendency for ${ }^{137} \mathrm{Cs}$ to be rapidly and firmly fixed upon its initial contact with the soil. Because ${ }^{137} \mathrm{Cs}$ is bound to soil particles with little or no leaching, it is an ideal indicator of soil redistribution for this research. 
Land use disturbance inferred from ${ }^{137} \mathrm{Cs}$ in sediments

The composition and size distribution of sediment during moderate and stormy conditions are similar to those of soil trapped over a tidal flat. Our results show that there are three main deposition layers in the profile of sediment deposits (Fig. 8). It is implied that there have been land use changes over time. The top layer showed tillage disturbance, with moderate sediments and new soil mixed from 0 to $20 \mathrm{~cm}$.

In the $0-20-\mathrm{cm}$ layer, the ${ }^{137} \mathrm{Cs}$ contents are generally less than $1.5 \mathrm{~Bq} / \mathrm{kg}^{-1}$. Based on common practice for check dam construction in the area, a new dam would be constructed when a check dam is filled with sediments to continue capturing sediment from the upstream reaches. A study in this area by Yang et al. (2006) and Zhang et al. (2006) indicated that most sediments are transported from the gully slopes or by gravity erosion. The ${ }^{137} \mathrm{Cs}$ content of the sediments is generally less than $1.0 \mathrm{~Bq} / \mathrm{kg}$ and averages $0.67 \mathrm{~Bq} / \mathrm{kg}$. Our investigation proved that local people excavated the surface soil of a gully slope to build a check dam to maintain suitable soil moisture. In another study on lake sediment, the sediment originating from the drainage areas contained low ${ }^{137} \mathrm{Cs}$ concentrations, which diluted the overall concentration of ${ }^{137} \mathrm{Cs}$ in the lake sediment (Ahn et al. 2009).

There is a transition stage of the wetland, such as from bulrushes to crops, in the $20-85 \mathrm{~cm}$ depth and this layer is marked by the mixed layer of farming activities in the years after 1963. This matched with the observed natural succession of aquatic plants that appear in the late deposition of a check dam. In this layer, the soil particle size distributions of the four cores are similar and uniform.

Obvious sedimentary layers and a lack of tillage disturbances were noted below a depth of $85 \mathrm{~cm}$. This indicates that the portion below $85 \mathrm{~cm}$ depth is derived from natural sedimentation processes. Using the A0 core as an example, from 250 to $550 \mathrm{~cm}$, the ${ }^{137} \mathrm{Cs}$ content decreased with depth. The results indicated that the deposition process of the sediments was under slow or immobile velocity conditions during a single erosive rainfall event. For a couplet that attributed to single erosive rainfall event, $\mathrm{Li}$ et al. (2009) and Zhang et al. (2006) noted that the bottom layer was coarse and had low ${ }^{137} \mathrm{Cs}$ content while the top layer was fine-silt with high ${ }^{137} \mathrm{Cs}$ content. This is a result of ${ }^{137} \mathrm{Cs}$ being prone
Fig. 8 Depth distributions of ${ }^{137} \mathrm{Cs}$ and sediment particle content (clay, silt, and sand) in the A0 deposit profile of dam I in the Yangjuangou watershed

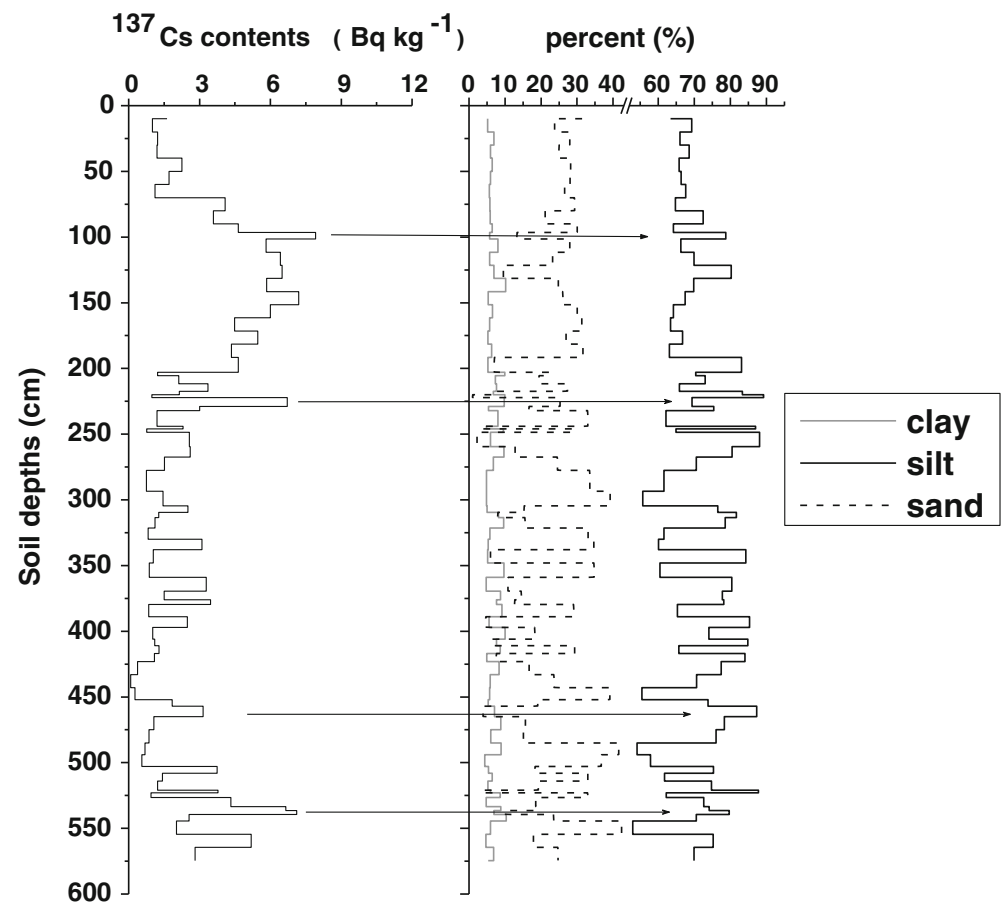


to absorption by fine-silt particles, while coarse sediment particles settle faster in the reservoir water body.

In all four cores, a significant pulse is located at the $100-200 \mathrm{~cm}$ depth, with the main peak in the $120-160 \mathrm{~cm}$ interval. This is coincident with a delayed main pulse of nuclear weapons testing that occurred in 1963 (Naegler and Levin 2006). It is clear that a rainfall event and the resulting soil erosion occurred on 10 September 1963. The ${ }^{137} \mathrm{Cs}$ content ranged from $6-8 \mathrm{~Bq} / \mathrm{kg}$. It appears that the deposition recorded in the radioisotope profiles occurred over many rainfall events. Based on the core at site A0, the rate of deposition (assuming 100-200 cm of down-core migration of ${ }^{137} \mathrm{Cs}$ ) ranged from 56.3$68.8 \mathrm{~mm}$ per year during the period of 1955 to 1963 . As an example in the A0 cores, the clay content of six layers (250-290, 305-330, 330-350, 400-440, 460-400, and $530-550 \mathrm{~cm}$ ) decreased with soil deposition depths, due to six rainfall events. Different thicknesses of sediment accumulation indicate the degree of rainfall erosion intensity (Zhang et al. 2006; 2008; Yang et al. 2006).

Other factors affecting sediments and soil erosion

Check dams have a long-term role to play in stabilizing gullies and reducing stream gradients and therefore reduce scour from channel beds and banks (ConesaGarcia and Garcia-Lorenzo 2009; Solaimani et al. 2008; Xu et al. 2006). The coefficient of variance of the soil particle size and ${ }^{137} \mathrm{Cs}$ in four cores are useful tools when analyzing the human influence or natural rainfall effect on the soil erosion process.

During the last 50 years, the establishment of check dams and a slight reduction in rainfall and its erosivity have led to a significant reduction in the sediment supply. It is difficult to assess the effectiveness of the check dams at this moment, as their effects are similar to those of the land use changes experienced within the catchment. In our study, the ${ }^{137} \mathrm{Cs}$ technology was used to provide estimates of erosion rates, based on the ${ }^{137} \mathrm{Cs}$ levels in sediment. The results show that the sediment deposition rate was approximately $62.5 \mathrm{~cm} /$ year at the A0 site from 1955 to 1963.

This would allow us to evaluate whether the control established by the land use changes was enough to decrease sediment supply before the establishment of the check dams. Sometimes, a very limited change in land use can have a significant effect on regional soil erosion rates (Van Rompaey et al. 2002). Changes in land uses causes changes in sediment yield, but changes in landscape structure have important consequences for sediment yield (Boix-Fayos et al. 2008).

\section{Conclusions}

We found that the grain-size feature of check dam sediment is closely influenced by the position within a check dam, forms of land use, and size of rainfall events. The advantages of environmental change research based on sediments collected by check dams are the higher time resolution of the information reconstructed and its implications for contemporary land use management. We can conclude that rainfall erosion extends according to the composition and size distribution of local and advected sediment trapped over a tidal flat during moderate and stormy conditions. Our results indicate that there are three main typical deposition layers in the profile of sediments deposited. Variability of sediment particle size and ${ }^{137} \mathrm{Cs}$ in sediments increases with the direction of runoff and the depth of deposition. In the profile of the check dam we studied, the ${ }^{137} \mathrm{Cs}$ distribution was a strong indicator of rainfall erosion, events especially in 1963. Check dams were widely constructed in the Loess Plateau in the 1960s. For this reason, the study of the sediments of these dams could provide insights into soil erosion and environmental changes that have occurred since 1955 in the Loess Plateau region.

Check dam sediments could be an important indicator of environmental change and its effect on soil erosion. The sediments may provide a multi-proxy record of soil erosion evolution at the local scale in the middle reach of the Yellow River. There is a wide distribution of temporal and spatial check dams in the Loess Plateau, and sediments from these dams could be collected to study the development of soil erosion in a semiarid area on a regional scale.

Acknowledgments The research was supported by the National Natural Science Foundation of China (nos. 40925003, and 40901098).

\section{References}

Ahn, Y. S., Nakamura, F., Kizuka, T., et al. (2009). Elevated sedimentation in lake records linked to agricultural activities in the Ishikari River floodplain, northern Japan. Earth Surface Processes and Landforms, 34, 1650-1660. 
Ayrault, S., Priadi, C. R., Evrard, O., et al. (2010). Silver and thallium historical trends in the Seine River basin. Journal of Environmental Monitoring, 12, 2177-2185.

Bellin, N., van Wesemael, B., Meerkerk, A., et al. (2009). Abandonment of soil and water conservation structures in Mediterranean ecosystems. A case study from south east Spain. Catena, 76, 114-121.

Boix-Fayos, C., Martínez-Mena, M., Calvo-Cases, A., et al. (2005). Concise review of interrill erosion studies in SE Spain (Alicante and Murcia): erosion rates and progress of knowledge from the 1980s. Land Degradation \& Development, 16, 517-528.

Boix-Fayos, C., Barbera, G. G., Lopez-Bermudez, F., \& Castillo, V. M. (2007). Effects of check dams, reforestation and landuse changes on river channel morphology: case study of the Rogativa catchment (Murcia, Spain). Geomorphology, 91, 103-123.

Boix-Fayos, C., de Vente, J., Martínez-Mena, M., et al. (2008). The impact of land use change and checkdams on catchment sediment yield. Hydrological Processes, 22, 4922-4935.

CMWR. (2003). Programming for check-dams in the Loess Plateau. Beijing: Resources CMoW.

Conesa-Garcia, C., \& Garcia-Lorenzo, R. (2009). Effectiveness of check dams in the control of general transitory bed scouring in semiarid catchment areas (south-east Spain). Water and Environment Journal, 23, 1-14.

Dearing, J., Hu, Y., Doody, P., et al. (2001). Preliminary reconstruction of sediment-source linkages for the past $6000 \mathrm{yr}$ at the Petit Lac d'Annecy, France, based on mineral magnetic data. Journal of Paleolimnology, 25, 245-258.

Dearing, J. A., Jones, R. T., Shen, J., et al. (2008). Using multiple archives to understand past and present climate-human-environment interactions: the lake Erhai catchment, Yunnan Province, China. Journal of Paleolimnology, 40, 3-31.

Dollar, E. S. J. (2004). Fluvial geomorphology. Progress in Physical Geography, 28, 405-450.

Fanetti, D., \& Vezzoli, L. (2007). Sediment input and evolution of lacustrine deltas: the Breggia and Greggio rivers case study (Lake Como, Italy). Quaternary International, 173, 113124.

Fang, H. Y., Li, Q. Y., Sun, L. Y., et al. (2012). Using Cs-137 to study spatial patterns of soil erosion and soil organic carbon (SOC) in an agricultural catchment of the typical black soil region, Northeast China. Journal of Environmental Radioactivity, 112, 125-132.

Fu, B. J., Chen, L. D., Ma, K. M., et al. (2000). The relationships between land use and soil conditions in the hilly area of the loess plateau in northern Shaanxi, China. Catena, 39, 69-78.

Fu, B. J., Wang, Y. F., Lu, Y. H., et al. (2009). The effects of landuse combinations on soil erosion: a case study in the Loess Plateau of China. Progress in Physical Geography, 33, 793804.

Girardclos, S., Fiore, J., Rachoud-Schneider, A. M., et al. (2005). Petit-Lac (western Lake Geneva) environment and climate history from deglaciation to the present: a synthesis. Boreas, 34, 417-433.

Hassanli, A. M., Nameghi A. E., \& Beecham S., (2009). Evaluation of the effect of porous check dam location on fine sediment retention (a case study). Environmental Monitoring and Assessment, 152, 319-326.
Jennings, A. E., Hagen, S., Harðardóttir, J., et al. (2001). Oceanographic change and terrestrial human impacts in a post A.D. 1400 sediment record from the Southwest Iceland Shelf. Climatic Change, 48, 83-100.

Kaiser, K., Lai, Z. P., Schneider, B., et al. (2009). Stratigraphy and palaeoenvironmental implications of Pleistocene and Holocene aeolian sediments in the Lhasa area, southern Tibet (China). Palaeogeography Palaeoclimatology Palaeoecology, 271, 329-342.

Klaminder, J., Appleby, P., Crook, P., et al. (2012). Post-deposition diffusion of $137 \mathrm{Cs}$ in lake sediment: implications for radiocaesium dating. Sedimentology, 59, 2259-2267.

Kou, X. J., Ge, J. P., Wang, Y, et al. (2007) Validation of the weather generator CLIGEN with daily precipitation data from the Loess Plateau, China. Journal of Hydrology, 347 (3-4), 347-357.

Laflen, J. M. (2000). Agricultural and environmental sustainability - a global perspective. In J. M. Laflen, C. H. Huang, J. Tian (Eds), Soil erosion and dryland farming. Proceedings of conference on soil erosion and dryland farming. Xian, China. September 1997, pp. 5-12. New York: CRC Press.

Li, W. (2001). Agro-ecological farming systems in China. New York: Taylor \& Francis. 262.

Li, X.-G., \& Wei, X. (2011). Soil erosion analysis of human influence on the controlled basin system of check dams in small watersheds of the Loess Plateau, China. Expert Systems with Applications, 38, 4228-4233.

Li, Y., Yang, J., Zhu, Y. (1997) Using ${ }^{137} \mathrm{Cs}$ and ${ }^{210} \mathrm{~Pb}$ to assess the sediment sources in a dam reservoir catchment on the Loess Plateau, China. In: China nuclear sciences and technology report. Beijing: Atomic Energy Press, 1-15.

Li, M., Li, Z., Yao W., \& Liu, P. (2009). Estimating the erosion and deposition rates in a small watershed by the $137 \mathrm{Cs}$ tracing method. Applied Radiation and Isotopes, 67(2), 362-366.

Li, Y., Poesen, J., Yang, J. C., et al. (2003). Evaluating gully erosion using $\mathrm{Cs}-137$ and $\mathrm{Pb}-210 / \mathrm{Cs}-137$ ratio in a reservoir catchment. Soil \& Tillage Research, 69, 107-115.

Lu, H., Moran, C. J., \& Prosser, I. P. (2006). Modelling sediment delivery ratio over the Murray Darling Basin. Environmental Modelling \& Software, 21, 1297-1308.

Mabit, L., Martin, P., Jankong, P., et al. (2010). Establishment of control site baseline data for erosion studies using radionuclides: a case study in East Slovenia. Journal of Environmental Radioactivity, 101, 854-863.

Meng, Q. (Ed.). (1996). Soil and water conservation in the Loess Plateau. Water Resource Press of Yellow River, 75, 316-317.

Miao, C. Y., Ni, J. R., \& Borthwick, A. G. L. (2010). Recent changes of water discharge and sediment load in the Yellow River basin, China. Progress in Physical Geography, 34, 541-561.

Miao, C. Y., Ni, J. R., Borthwick, A. G. L., et al. (2011). A preliminary estimate of human and natural contributions to the changes in water discharge and sediment load in the Yellow River. Global and Planetary Change, 76, 196-205.

Miao, C. Y., Shi, W., Chen, X. H., et al. (2012). Spatio-temporal variability of streamflow in the Yellow River: possible causes and implications. Hydrological Sciences Journal/Journal Des Sciences Hydrologiques, 57, 1355-1367. 
Nadal-Romero, E., Regues, D., \& Latron, J. (2008). Relationships among rainfall, runoff, and suspended sediment in a small catchment with badlands. Catena, 74, 127-136.

Naegler, T., \& Levin, I. (2006). Closing the global radiocarbon budget 1945-2005. Journal of Geophysical Research Part D: Atmospheres, 111(D12).

Picot, L., Becker, D., Lapaire, F., et al. (2005). Sedimentology, palaeontology and coastal paleoenvironments of Porrentruy area (South Rhine Graben, Paleogene, Jura, Switzerland): geodynamical implications. Eclogae Geologicae Helvetiae, 98, 281-296.

Pimentel, D., Harvey, C., Resosudarmo, P., et al. (1995). Environmental and economic costs of soil erosion and conservation benefits. Science, 267, 1117-1123.

Ritchie, J. C., \& Mchenry, J. R. (1990). Application of radioactive fallout cesium-137 for measuring soil-erosion and sediment accumulation rates and patterns - a review. Journal of Environmental Quality, 19, 215-233.

Ritchie, J. C., Herrick, J. E., \& Ritchie, C. A. (2003). Variability in soil redistribution in the northern Chihuahuan Desert based on 137Cesium measurements. Journal of Arid Environments, 55, 737-746.

Ritchie, J. C., Finney, V. L., Oster, K. J., et al. (2004). Sediment deposition in the flood plain of Stemple Creek Watershed, northern California. Geomorphology, 61, 347-360.

Schuller, P., Walling, D. E., Sepulveda, A., et al. (2007). Changes in soil erosion associated with the shift from conventional tillage to a no-tillage system, documented using 137Cs measurements. Soil and Tillage Research, 94, 183-192.

Solaimani, K., Omidvar, E., \& Kelarestaghi, A. (2008). Investigation of check dam's effects on channel morphology (case study: Chehel cheshme watershed). Pakistan Journal of Biological Sciences, 11, 2083-2091.

Stroosnijder, L. (2005). Measurement of erosion: is it possible? Catena, 64, 162-173.

Tian, P., Zhao, G. J., Mu, X. M., et al. (2013). Check dam identification using multisource data and their effects on streamflow and sediment load in a Chinese Loess Plateau catchment. Journal of Applied Remote Sensing, 7(1), 073697.

Van Rompaey, A. J. J., Govers, G., \& Puttemans, C. (2002). Modelling land use changes and their impact on soil erosion and sediment supply to rivers. Earth Surface Processes and Landforms, 27, 481-494.

Vott, A., Bruckner, H., Handl, M., et al. (2006). Holocene palaeogeographies of the Astakos coastal plain (Akarnania, NW Greece). Palaeogeography Palaeoclimatology Palaeoecology, 239, 126-146.

Walling, D. E. (2005). Tracing suspended sediment sources in catchments and river systems. Science of The Total Environment, 344, 159-184.

Walling, D. E., \& He, Q. (1997). Use of fallout 137 Cs in investigations of overbank sediment deposition on river floodplains. Catena, 29, 263-282.

Walling, D. E., Owens, P. N., \& Leeks, G. J. L. (1997). The characteristics of overbank deposits associated with a major flood event in the catchment of the River Ouse, Yorkshire, UK. Catena, 31, 53-75.

Walling, D. E., Collins, A. L., Jones, P. A., et al. (2006). Establishing fine-grained sediment budgets for the Pang and Lambourn LOCAR catchments, UK. Journal of Hydrology, 330, 126-141.

Wasson, R. J., Caitcheon, G., Murray, A. S., et al. (2002). Sourcing sediment using multiple tracers in the catchment of Lake Argyle, northwestern Australia. Environmental Management, 29, 634-646.

Wei, W., Chen, L., Fu, B., Huang, Z., Wu, D., \& Gui L., (2007). The effect of land uses and rainfall regimes on runoff and soil erosion in the semi-arid loess hilly area, China. Journal of Hydrology, 335(3-4), 247-258.

Xu, X. Z., Zhang, H. W., \& Zhang, O. Y. (2004). Development of check-dam systems in gullies on the Loess Plateau, China. Environmental Science \& Policy, 7, 79-86.

Xu, X. Z., Zhang, H. W., Wang, G. Q., et al. (2006). A laboratory study on the relative stability of the check-dam system in the Loess Plateau, China. Land Degradation \& Development, 17, 629-644.

Xu, X. Z., Zhang, H. W., Wang, G. Q., et al. (2009). An experimental method to verify soil conservation by check dams on the Loess Plateau, China. Environmental Monitoring and Assessment, 159, 293-309.

Yang, M.-Y., Tian, J.-L., \& Liu, P.-L. (2006). Investigating the spatial distribution of soil erosion and deposition in a small catchment on the Loess Plateau of China, using 137Cs. Soil and Tillage Research, 87, 186-193.

Zhang, X., Higgitt, D. L., \& Walling, D. E. (1990). A preliminary assessment of the potential for using caesium-137 to estimate rates of soil erosion in the Loess Plateau of China. Hydrological Sciences Journal, 35, 243-252.

Zhang, X., Walling, D. E., Yang, Q., et al. (2006). 137Cs budget during the period of 1960 s in a small drainage basin on the Loess Plateau of China. Journal of Environmental Radioactivity, 86, 78-91.

Zhang, X. B., Wen, Z. M., Feng, M. Y., et al. (2007). Application Of (CS)-C-137 fingerprinting technique to interpreting sediment production records from reservoir deposits in a small catchment of the Hilly Loess Plateau, China. Science in China Series D-Earth Sciences, 50, 254-260.

Zhang, Y., Liu, B., Wang, Z., et al. (2008). Evaluation of CLIGEN for storm generation on the semiarid Loess Plateau in China. Catena, 73, 1-9.

Zhang, X. B., Bai, X. Y., \& Liu, X. M. (2011). Application of a Cs137 fingerprinting technique for interpreting responses of sediment deposition of a karst depression to deforestation in the Guizhou Plateau, China. Science China-Earth Sciences, 54, 431-437.

Zheng, M. G., Qin, F., Yang, J. S., et al. (2013). The spatio-temporal invariability of sediment concentration and the flow-sediment relationship for hilly areas of the Chinese Loess Plateau. Catena, 109, 164-176. 